\title{
STOCK VALUATION BY USING PRICE EARNING RATIO (PER) IN STOCK INDEX $L Q 45$
}

\author{
Suryanto \\ Department of Business Administration Science \\ Faculty of Social and Political Science, Padjadjaran University \\ Email : suryanto@unpad.ac.id
}

\begin{abstract}
Stock valuations are reasonable assessment of the price of the stock. Stock valuations done to anticipate potential losses that would be received by investors. This research aims to determine the fair price of stocks and stock picks eligible to be selected in the investment in shares LQ45 index. The method used in this research is descriptive analysis with quantitative approach. The sampling technique purposive sampling of issuers incorporated in LQ45 index period from February 2016. The valuation of the stock price is measured by using the approach of Price Earning Ratio (PER). In conclusion, the results of valuations can be seen that 10 of the 13 companies, namely AKRA, ASII, $B B C A, B B N I, B B R I, J S M R, L K P R, M P P A$, UNTR and UNVR all in condition undervalued. This means that the shares are relatively cheap. As for the stock ADRO, BMRI, and SCMA in condition overvalued, which means that the shares are expensive.
\end{abstract}

Keywords: valuation of shares, price earning ratio

\section{VALUASI SAHAM DENGAN MENGGUNAKAN METODE PRICE EARNING RATIO (PER) PADA SAHAM INDEKS LQ45}

\begin{abstract}
ABSTRAK
Valuasi saham merupakan penilaian terhadap harga yang wajar terhadap suatu saham. Valuasi saham dilakukan untuk mengantisipasi potensi kerugian yang akan diterima investor. Penelitian ini bertujuan untuk mengetahui harga wajar saham dan memilih saham yang layak untuk dijadikan pilihan dalam investasi pada saham Indeks LQ45. Metode yang digunakan dalam penelitian ini adalah analisis deskriptif dengan pendekatan kuantitatif. Teknik pengambilan sampel dengan purposive sampling dari emiten yang tergabung dalam Indeks LQ45 periode Februari 2016. Valuasi harga saham diukur dengan menggunakan pendekatan Price Earning Ratio (PER). Kesimpulannya, dari hasil valuasi saham dapat diketahui bahwa 10 dari 13 perusahaan, yaitu AKRA, ASII, BBCA, BBNI, BBRI, JSMR, LKPR, MPPA, UNTR dan UNVR semua dalam kondisi undervalued. Hal tersebut berarti sahamsaham tersebut tergolong murah. Sedangkan untuk saham ADRO, BMRI, dan SCMA dalam kondisi overvalued, yang berarti saham tersebut tergolong mahal.
\end{abstract}

Kata kunci : valuasi saham, price earning ratio 


\section{PENDAHULUAN}

Minat orang Indonesia untuk berinvestasi di pasar modal meningkat selama beberapa tahun terakhir. Jumlah investor per 28 Desember 2015 tercatat 433.607 investor yang memiliki rekening di Bursa Efek Indonesia (BEI). Jumlah tersebut lebih tinggi dibandingkan akhir Desember 2014 yang hanya 364.465 investor.

Walaupun indeks harga saham gabungan (IHSG) sepanjang 2015 kurang baik, namun secara jangka panjang, pertumbuhan IHSG dalam enam tahun terakhir dari 2009 hingga 2015 masih positif dengan membukukan pertumbuhan imbal hasil akumulatif sekitar 79,82 persen.

Fenomena sebagaimana telah dijelaskan di atas menjelaskan bahwa terjadi perkembangan pasar modal Indonesia yang cukup menggembirakan pada beberapa tahun belakangan ini. Hal ini juga menunjukan bahwa pasar modal merupakan salah satu bidang jasa keuangan di Indonesia yang cukup diminati. Banyak masyarakat yang membeli saham dengan alasan yang sama, yaitu mereka menginginkan return yang didapati dari saham yang dimilikinya.

Investasi saham bukanlah tidak beresiko. Investasi pad saham merupakan investasi pada sektor finansial yang tergolong paling high riskhigh return investment. Artinya, peluang untuk memperoleh keuntungan sangat besar bahkan dapat mencapai ratusan persen perbulan namun diimbangi dengan kemungkinan kerugian yang besar apabila tidak dikelola dengan baik. Salah satu resiko dari investasi di dalam saham adalah harga saham yang cenderung fluktuatif. Apabila investor kita membeli saham sekarang dengan harga yang relatif kecil, bukan berarti harga saham tersebut pada satu tahun yang akan datang akan tetap sama. Saham tersebut kemungkinan akan mengalami kenaikan atau bahkan penurunan harga saham.

Pada dasarnya, semua jenis investasi memiliki kemungkinan merugi. Besarnya potensi kerugian akan sebanding dengan besarnya potensi keuntungan yang dapat diperoleh. Oleh karena itu, sangat penting bagi investor untuk melakukan penilaian (valuasi) terhadap saham dengan cermat untuk meminimalkan resiko. Seringkali hasil valuasi harga saham tidak memiliki nilai yang sama dengan harga saham yang diperdagangkan di pasar modal. Kondisi seperti inilah yang dikatakan overvalued atau undervalued. Apabila hasil valuasi saham lebih rendah dibandingkan harga pasar, maka saham tersebut dikatakan overvalued berarti saham tersebut tidak layak untuk dibeli. Sebaliknya, jika suatu saham menunjukkan valuasi yang lebih tinggi dibandingkan harga pasar, maka saham tersebut diakatak undervalued berarti saham tersebut layak untuk dibeli.

Valuasi saham perlu dilakukan sebelum mengambil keputusan investasi. Melakukan valuasi harga saham, berarti menilai berapa harga yang wajar suatu saham. Menurut Damodaran (2002), penilaian harga wajar saham adalah proses membandingkan nilai riil suatu saham dengan harga yang berlaku di pasar dengan memperhatikan faktor fundamental. Faktor-faktor fundamental yang mempengaruhi nilai biasanya lebih lambat perubahannya dibandingkan perubahan harga pasar. Di dalam pasar yang tidak sempuna, penilaian saham dapat melokalisir variances (perbedaan) antara nilai wajar dengan harga permintaan menurut pasar.

Penelitian mengenai valuasi saham sebelumnya sudah dilakukan oleh Sri Dwi Ari Ambarwati (2008), yang meneliti keterkaitan nilai dividen antara perusahaan IOS tinggi dengan perusahaan IOS rendah dengan menggunakan metode Dividend Yield dan Price Earning Ratio (PER). Penelitian berikutnya dilakukan oleh Nazwirman (2008), dengan tujuan mendapatkan gambaran yang lebih jelas mengenai metode PER dan aplikasinya dalam penilaian investasi saham. Hasil penelitiannya menyimpulkan bahwa pendekatan PER merupakan salah satu pendekatan yang populer di kalangan analisis dan praktisi saham. Penelitian yang sama juga telah dilakukan Marmono (2012) dan Irene Silvia Permata, Kertahadi, dan Topowijono (2013) bahwa valuasi dengan menggunakan PER merupakan pendekatan yang lebih mendekati nilai ril harga pasar saham. 
Berdasarkan fenomena yang terjadi bahwa harga saham selalu berfluktuasi, maka dibutuhkan adanya petunjuk bagi investor atau calon investor secara real time untuk membuat keputusan berkaitan dengan keputusan investasi.

\section{TINJAUAN PUSTAKA}

Saham menurut Bodie, Kane \& Marcus (2006:59) menunjukkan bagian kepemilikan di sebuah perusahaan. Untuk melihat kewajaran nilai suatu saham dapat dilakukan valuasi terhadap saham tersebut. Menurut Asnawi dan Wijaya (2006:198) valuasi saham adalah mengestimasi nilai saham yang sebenarnya (intrinsic value) berdasarkan data fundamentalnya. Menurut Tambunan (2007:217), harga wajar atau nilai intrinsik suatu aset adalah suatu harga yang dapat kita terima sebagai harga pokok kepemilikan suatu aset setelah membandingkan tingkat imbal hasil yang kita harapkan (required rate of return) dengan tingkat imbal hasil yang dapat diberikan aset tersebut di masa mendatang (expected rate of return). Sedangkan menurut Damodaran (2002), penilaian harga wajar saham adalah proses membandingkan nilai riil suatu saham dengan harga yang berlaku di pasar dengan memperhatikan faktor fundamental

Model valuasi saham menurut Tandelilin (2010:301) terdiri dari tiga jenis nilai, yaitu nilai buku, nilai pasar dan nilai intrinsik. Nilai buku adalah nilai yang dihitung berdasarkan pembukuan perusahaan penerbit saham (emiten). Nilai pasar adalah nilai saham didalam pasar modal yang ditunjukkan oleh harga saham tersebut dipasar modal. Nilai intrinsik atau dikenal sebagai nilai teoritis adalah nilai saham yang sebenarnya atau yang seharusnya terjadi. Nilai ini yang biasanya disebut sebagai nilai wajar suatu saham.

Analisis valuasi saham menurut Tandelilin (2010:301) bertujuan untuk menghasilkan informasi nilai intrinsik suatu saham kemudian dibandingkan dengan harga pasar saham saat ini. Analisis penilaian saham dilakukan dengan mempertimbangkan faktor-faktor fundamental suatu perusahaan. Dengan melakukan analisis valuasi saham menurut Abdul Halim (2005:5) dapat diketahui apakah harga saham tersebut berada dalam kondisi undervalued atau overvalued. Harga saham yang overvalued menunjukkan bahwa harga saham yang ada di pasar dinilai terlalu mahal karena dihargai lebih tinggi dari nilai intrinsiknya (harga wajar saham). Sebaliknya, jika harga saham tersebut pada kondisi undervalued maka saham tersebut dihargai terlalu murah karena harganya dinilai lebih rendah dari nilai intrisiknya. Harga saham dikatakan wajar bila dihargai sama dengan nilai intrinsiknya

Salah satu analisis fundamental yang dapat digunakan untuk menilai kewajaran harga saham adalah Price Earnings Ratios (PER) (Alexander and Sharpe, 1995:117). Jones (2004) mengartikan "PER is simply the number of times investors value earnings as expressed in the stock price". Sedangkan Jogiyanto (2010:146) menyatakan bahwa PER menunjukkan rasio harga saham terhadap earning atau dengan kata lain menunjukkan berapa besar pemodal menilai harga saham terhadap kelipatan dari earnings, sehingga dapat disimpulkan bahwa PER menggambarkan apresiasi pasar terhadap kemampuan perusahaan dalam menghasilkan laba.

PER merupakan variabel yang digunakan dalam estimasi nilai intrinsik saham yaitu dengan mengalikannya dengan Earning Per Share (EPS) yang diharapkan. EPS atau laba per saham adalah rasio yang mengukur pendapatan bersih perusahaan pada suatu periode dibagi dengan jumlah saham yang beredar. Ketika investor mengevaluasi performance dari perusahaan, investor tidak cukup hanya mengetahui apakah income suatu perusahaan mengalami kenaikan atau penurunan, investor juga perlu mencermati bagaimana perubahan income berakibat terhadap investasinya. James Gill dan Moira Chatton (2003:66) menyatakan bahwa perusahaan yang mapan umumnya mempunyai rasio EPS tinggi sedangkan perusahaan yang berusia muda mempunyai kecenderungan EPS yang rendah. Dengan kata lain, nilai intrinsik suatu saham juga 
merupakan fungsi EPS yang diharapkan dan besarnya PER saham tersebut.

Bagi investor, semakin kecil PER suatu saham, semakin bagus karena saham tersebut termasuk dalam kategori murah (Darmadji dan Fakhrudin, 2006:198). Adler Haymans Manurung (2004:27) juga mengemukakan bahwa PER dipergunakan oleh berbagai pihak atau investor untuk membeli saham. Investor akan membeli suatu saham perusahaan dengan PER yang kecil, karena PER yang kecil menggambarkan laba bersih per saham yang cukup tinggi dan harga saham yang rendah.

\section{METODE PENELITIAN}

Data yang digunakan dalam penelitian ini bersumber dari laporan keuangan yang diterbitkan oleh perusahaan yang tergabung adalam Indeks LQ45 periode Februari 2016. Sampling yang digunakan dalam penelitian ini adalah purposive sampling yaitu kelompok Indeks LQ45 yang membagikan dividen di tahun 2016. Adapun emiten yang tergabung dalam Indeks LQ45 yang membagikan deviden hanya 13 emiten. Jadi yang akan dilakukan valuasi dalam penelitian ini hanya terfokus pada 13 emiten tersebut.

Beberapa faktor yang perlu diperhatikan dalam menghitung PER (Husnan, 2003) :

1. Menghitung tingkat pertumbuhan lexpected earnings growth rate $(\mathrm{g})$ :

$g=\mathrm{ROE} \times b ; \quad$ bilamana $b=1-\mathrm{DPR}$

Dimana

$g \quad=$ expected earnings growth rate

ROE = Return on Equity periode pengamatan

$b \quad=$ tingkat laba ditahan

DPR $=$ Devident Payout Ratio periode pengamatan

2. Menentukan estimated cash Dividend per Share (DPS)

$D P S_{1}=D P S \times(1+g)$

Dimana:

DPS = Devident per Share

$D P S_{1}=$ estimasi Devident per Share
3. Menentukan estimated Earnings per Share (EPS)

$$
\begin{aligned}
& E P S_{1}=E P S \times(1+g) \\
& E P S=\text { Earning per Share } \\
& E P S_{1}=\text { estimasi Earning per Share }
\end{aligned}
$$

4. Menentukan nilai expected return (k)

$$
\begin{aligned}
& k=\frac{D P S_{1}}{P_{0}}+g \\
& P_{0} \quad \text { = harga saham periode sebelumnya }
\end{aligned}
$$

5. Menghitung estimated PER

$$
P E R_{\text {estimated }}=\frac{D P S_{1} / E P S_{1}}{k-g}
$$

\section{Menghitung nilai intrinsic saham}

Nilai intrinsik $=$ Estimated EPS $\times$ Estimated PER

Tahap selanjutnya adalah membandingkan nilai intrinsic saham hasil perhitungan dengan

\begin{tabular}{|c|c|c|}
\hline Keterangan & $\begin{array}{c}\text { Kondisi Harga } \\
\text { saham }\end{array}$ & Keputusan investasi \\
\hline $\begin{array}{l}\text { Bila nilai } \\
\text { intrinsic > } \\
\text { harga pasar }\end{array}$ & $\begin{array}{l}\text { Harga saham } \\
\text { terlalu murah } \\
\text { (undervalued) }\end{array}$ & $\begin{array}{l}\text { Membeli karena } \\
\text { dimungkinkan harga } \\
\text { akan naik }\end{array}$ \\
\hline $\begin{array}{l}\text { Bila nilai } \\
\text { intrinsic }< \\
\text { harga pasar }\end{array}$ & $\begin{array}{l}\text { Harga saham } \\
\text { terlalu mahal } \\
\text { (overvalued) }\end{array}$ & $\begin{array}{l}\text { Menjual karena } \\
\text { dimungkinkan harga } \\
\text { akan jatuh }\end{array}$ \\
\hline $\begin{array}{l}\text { Bila nilai } \\
\text { intrinsic }= \\
\text { harga pasar }\end{array}$ & $\begin{array}{l}\text { Harga saham } \\
\text { wajar atau } \\
\text { normal } \\
\text { (correctly } \\
\text { valued) }\end{array}$ & $\begin{array}{l}\text { Menahan (tidak } \\
\text { menjual atau } \\
\text { membeli) hingga ada } \\
\text { waktu dimana terjadi } \\
\text { estimated earnings } \\
\text { bagi investor }\end{array}$ \\
\hline
\end{tabular}
rumus di atas dengan nilai saham atau harga pasar yang sesungguhnya. Prosedur penilaian kewajaran harga saham dilakukan dengan cara berikut:

Tabel 1. Kriteria Keputusan Investasi

\section{HASIL DAN PEMBAHASAN}

Kelompok LQ45 periode Februari 2016 hanya ada 13 emiten yang membagikan deviden, sedangkan sisanya sebanyak 32 emiten belum diputuskan apakah akan membagikan deviden atau tidak. Ketiga belas emiten yang membagaikan deviden berasal dari beberapa kelompok industri yang berbeda. 
Adapun emiten yang membagikan deviden untuk perusahaan yang tergabung dalam Indeks LQ45 periode Februari 2016 adalah sebagai berikut:

Tabel 2. Emiten Indeks LQ45 yang Membagikan Deviden

\begin{tabular}{|l|l|l|l|}
\hline No & Kode & Perusahaan & Kelompok Industri \\
\hline 1 & ADRO & $\begin{array}{l}\text { Adaro Energi, } \\
\text { Tbk }\end{array}$ & Coal Mining \\
\hline 2 & AKRA & $\begin{array}{l}\text { AKR } \\
\text { Corporindo, Tbk }\end{array}$ & Wholesale \\
\hline 3 & ASII & $\begin{array}{l}\text { Astra } \\
\text { International, } \\
\text { Tbk }\end{array}$ & $\begin{array}{l}\text { Automotive and } \\
\text { Components }\end{array}$ \\
\hline 4 & BBCA & $\begin{array}{l}\text { Bank Central } \\
\text { Asia, Tbk }\end{array}$ & Bank \\
\hline 5 & BBNI & $\begin{array}{l}\text { Bank Negara } \\
\text { Indonesia, Tbk }\end{array}$ & Bank \\
\hline 6 & BBRI & $\begin{array}{l}\text { Bank Rakyat } \\
\text { Indonesia, Tbk }\end{array}$ & Bank \\
\hline 7 & BMRI & Bank Mandiri & Bank \\
\hline 8 & JSMR & $\begin{array}{l}\text { Jasa Marga } \\
\text { (Persero), Tbk }\end{array}$ & $\begin{array}{l}\text { Toll Road, } \\
\text { Airport, Harbor } \\
\text { and Allied Product }\end{array}$ \\
\hline 9 & LKPR & $\begin{array}{l}\text { Lippo Karawaci, } \\
\text { Tbk }\end{array}$ & $\begin{array}{l}\text { Property and Real } \\
\text { Estate }\end{array}$ \\
\hline 10 & MPPA & $\begin{array}{l}\text { Matahari Putra } \\
\text { Prima, Tbk }\end{array}$ & Retail Trade \\
\hline 11 & SCMA & $\begin{array}{l}\text { Surya Cipta } \\
\text { Media, Tbk }\end{array}$ & $\begin{array}{l}\text { Advertising, } \\
\text { Printing, and } \\
\text { Media }\end{array}$ \\
\hline 12 & UNTR & $\begin{array}{l}\text { United Tractors, } \\
\text { Tbk }\end{array}$ & Wholesale \\
\hline 13 & UNVR & $\begin{array}{l}\text { Uniliver } \\
\text { Indonesia, Tbk }\end{array}$ & $\begin{array}{l}\text { Cosmetic and } \\
\text { Household }\end{array}$ \\
\hline Sumb & Lap & \\
\hline
\end{tabular}

Sumber : Laporan BEI, 2016

Valuasi saham dengan menggunakan PER oleh investor dilakukan dengan tujuan untuk mengetahui berapa kali (multiplier) nilai earning yang tercermin dalam harga saham. Karena PER merupakan ukuran untuk menentukan bagaimana pasar memberi nilai atau harga pada saham perusahaan. Keinginan investor melakukan analisis saham dengan PER, dikarenakan adanya keinginan investor atau calon investor akan hasil (return) yang layak dari suatu investasi saham.

Komponen penting dalam menghitung nilai instrinsik saham dengan pendekatan PER meliputi ROE, DPR, dan EPS. Adapun data ROE, DPS dan EPS emiten yang menjadi emiten pengamatan adalah sebagai berikut:
Tabel 3. Data ROE, DPR, dan EPS Emiten Tahun 2015

\begin{tabular}{|c|c|r|r|r|}
\hline No & Kode & \multicolumn{1}{c|}{ ROE } & \multicolumn{1}{c|}{ DPR } & \multicolumn{1}{c|}{ EPS (Rp) } \\
\hline 1 & ADRO & $4,50 \%$ & $23,25 \%$ & 65,74 \\
\hline 2 & AKRA & $14,53 \%$ & $38,12 \%$ & 262,36 \\
\hline 3 & ASII & $12,34 \%$ & $17,91 \%$ & 357,31 \\
\hline 4 & BBCA & $20,12 \%$ & $7,53 \%$ & 730,83 \\
\hline 5 & BBNI & $11,65 \%$ & $25,20 \%$ & 486,18 \\
\hline 6 & BBRI & $22,46 \%$ & $30,27 \%$ & $1.029,53$ \\
\hline 7 & BMRI & $17,70 \%$ & $30,00 \%$ & 871,5 \\
\hline 8 & JSMR & $10,67 \%$ & $20,24 \%$ & 213,14 \\
\hline 9 & LKPR & $5,41 \%$ & $15,09 \%$ & 23,2 \\
\hline 10 & MPPA & $6,59 \%$ & $20,57 \%$ & 34,03 \\
\hline 11 & SCMA & $44,57 \%$ & $52,78 \%$ & 104,2 \\
\hline 12 & UNTR & $7,11 \%$ & $24,30 \%$ & $1.033,07$ \\
\hline 13 & UNVR & $121,22 \%$ & $44,59 \%$ & 766,95 \\
\hline
\end{tabular}

Dari data tersebut terlihat bahwa semua emiten mempunyai ROE yang positif. ROE menunjukkan kemampuan perusahaan dalam menghasilkan leba bersih dengan modal sendiri yang dimilikinya. Makin besar ROE menujukkan kemampuan perusahaan menghasilkan laba bersih dengan modal sendiri yang dimiliki semakin besar. Emiten dengan ROE tertinggi dibukukan oleh Uniliver Indonesia (UNVR) dengan angka yang cukup tinggi yaitu 12,22\%. Sedangkan ROE terendah diperoleh oleh Adaro Energy dengan nilai ROE hanya 4,50\%.

Komponen DPR menjadi komponen kedua dalam menentukan nilai instrinsik saham. DPR menunjukkan kebijakan perusahaan dalam membagikan dividen kepada para pemegang saham. Semakin besar DPR suatu perusahaan, maka laba yang akan diterima oleh para pemegang saham akan semakin besar. Berdasarkan data tersebut di atas DPR tertinggi dilakukan oleh Surya Cipta Media dengan persentasenya mencapai $52,78 \%$. Sedangkan DPR terkecil dilakukan oleh Bank Centra Asia dengan persentase $7,53 \%$.

Komponen penting yang ketiga adalah laba per lembar saham atau lebih dikenal sebagai Earning per Share (EPS). Informasi EPS suatu perusahaan menunjukkan besarnya laba bersih perusahaan yang siap dibagikan bagi semua pemegang saham perusahaan. Semakin besar nilai EPS berarti nilai laba yang akan diterima 
oleh para pemegang saham semakin besar.

Perhitungan nilai instrinsik saham dengan metode PER dilakukan dengan

Berdasarkan hasil perhitungan valuasi saham dengan metode PER, maka diperoleh nilai instrinsik saham sebagai berikut:

Tabel 4. Nilai Instrinsik Saham

\begin{tabular}{|l|l|l|l|l|}
\hline No & Perusahaan & $\begin{array}{l}\text { Estimasi } \\
\text { PER }\end{array}$ & $\begin{array}{l}\text { Estimasi } \\
\text { EPS }\end{array}$ & $\begin{array}{l}\text { Nilai } \\
\text { Intinsik } \\
(\mathrm{Rp})\end{array}$ \\
\hline 1 & ADRO & 7,48 & 68,74 & 514 \\
\hline 2 & AKRA & 25,11 & 85,95 & 7.180 \\
\hline 3 & ASII & 15,25 & 393,51 & 6.001 \\
\hline 4 & BBCA & 15,50 & 66,76 & 13.435 \\
\hline 5 & BBNI & 9,29 & 28,53 & 4.910 \\
\hline 6 & BBRI & 9,60 & $1.190,75$ & 11.431 \\
\hline 7 & BMRI & 9,44 & 979,48 & 9.246 \\
\hline 8 & JSMR & 22,60 & 231,28 & 5.227 \\
\hline 9 & LKPR & 43,10 & 24,26 & 1.046 \\
\hline 10 & MPPA & 51,50 & 35,81 & 1.844 \\
\hline 11 & SCMA & 24,53 & 126,13 & 3.094 \\
\hline 12 & UNTR & 15,59 & $1.088,65$ & 16.972 \\
\hline 13 & UNVR & 28,82 & $1.282,11$ & 36.950 \\
\hline
\end{tabular}

Untuk menganalisi apakah saham ke-13 emiten tersebut undervalue atau overvalue, maka harus dibandingkan dengan harga saham emiten di pasar. Harga emiten di pasar diperoleh dari closing price masing-masing emiten di Bursa Efek Indonesia.

Keputusan investasi dilakukan setelah membandingkan nilai instrinsik saham dengan nilai pasar saham. Overvalued terjadi bila harga pasar saham lebih tinggi atau lebih mahal dibandingkan dengan nilai instrinsik saham, sedangkan undervalue terjadi apabilai nilai pasar saham dibawah atau lebih murah dari nilai instrinsik saham.
Tabel 5. Hasil Valuasi Saham

\begin{tabular}{|c|c|r|r|c|}
\hline No & Emiten & \multicolumn{1}{c|}{$\begin{array}{c}\text { Nilai } \\
\text { Intinsik } \\
(\mathrm{Rp})\end{array}$} & \multicolumn{1}{c|}{$\begin{array}{c}\text { Nilai } \\
\text { Pasar (Rp }\end{array}$} & Hasil \\
\hline 1 & ADRO & 514 & 515 & Overvalue \\
\hline 2 & AKRA & 7.180 & 7.175 & Undervalue \\
\hline 3 & ASII & 6.001 & 6.000 & Undervalue \\
\hline 4 & BBCA & 13.435 & 13.300 & Undervalue \\
\hline 5 & BBNI & 4.910 & 4.900 & Undervalue \\
\hline 6 & BBRI & 11.431 & 11.425 & Undervalue \\
\hline 7 & BMRI & 9.246 & 9.250 & Overvalue \\
\hline 8 & JSMR & 5.227 & 5.225 & Undervalue \\
\hline 9 & LKPR & 1.046 & 1.035 & Undervalue \\
\hline 10 & MPPA & 1.844 & 1.825 & Undervalue \\
\hline 11 & SCMA & 3.094 & 3.100 & Overvalue \\
\hline 12 & UNTR & 16.972 & 16.950 & Undervalue \\
\hline 13 & UNVR & 36.950 & 37.000 & Undervalue \\
\hline
\end{tabular}

Pada tabel 5 menunjukkan saham adro, bmri dan SCMA nilai instrinsiknya lebih kecil dibandingkan dengan nilai pasarnya, sehingga saham tersebut merupakan saham yang overvalued. Kondisi tersebut menunjukkan bahwa saham tersebut tidak layak untuk dibeli. Sedangkan bagi investor yang sudah memiliki saham tersebut, sebaiknya segera menjual saham tersebut.

Saham-saham yang layak untuk dibeli adalah AKRA, ASCII, BBCA, BBNI, BBRI, JSMR, LKPR, MPPA, UNTR, dan UNVR. Sahamsaham tersebut berada dalam kondisi undervalued karena nilai instrinsik saham lebih besar dibandingkan harga pasar saham tersebut. Bagi investor yang kebetulan sudah memiliki saham AKRA, ASCII, BBCA, BBNI, BBRI, JSMR, LKPR, MPPA, UNTR, dan UNVR sebaiknya tidak menjual saham tersebut karena saham tersebut berpotensi harganya akan naik. Walaupun saham-saham tersebut berada pada kondisi undervalued, namun saham yang paling baik adalah saham BBNI dan BBRI, karena memiliki estimasi nilai PER yang paling kecil.

PER yang kecil merupakan salah satu pertimbangan utama bagi value investing di samping faktor-faktor lainnya. PER merupakan angka psikologis bagi value investor dimana PER yang kecil akan lebih menarik dibandingkan dengan PER tinggi. PER rendah ini disebabkan 
oleh laba per saham yang relatif tinggi dibandingkan dengan harga sahamnya, sehingga tingkat return-nya lebih baik.

Saham-saham AKRA, ASCI, BBCA, JSMR, LKPR, MPPA, UNTR, dan UNVR layak untuk dibeli, tetapi untuk jangka pendek (short-run) atau trading dengan pertimbangan teknikal. Tetapi untuk investasi jangka panjang, sahamsaham tersebut mempunyai volatilitas yang tinggi sehingga memiliki potensi risiko yang tinggi pula.

\section{SIMPULAN}

Hasil penelitian dan pembahasan mengenai analisis valuasi saham dengan menggunakan Metode Price Earning Ratio pada Indeks LQ45 periode Februari 2016 menghasilkan kesimpulan sebagai berikut :

a. Setelah melakukan perhitungan nilai instrinsik dari saham-saham perusahaan yang tergabung dalam Indeks LQ45 dan membandingkan nilai instrinsik perusahaan dengan harga pasar, dapat diketahui bahwa 10 dari 13 emiten yang menjadi sampel yaitu AKRA, ASCII, BBCA, BBNI, BBRI, JSMR, LKPR, MPPA, UNTR, dan UNVR semua dalam kondisi undervalued, sedangkan untuk saham-saham adro, bmri dan SCMA dalam kondisi overvalued.

b. Saham-saham yang layak untuk dibeli adalah saham-saham yang tergolong undervalued yaitu AKRA, ASCII, BBCA, BBNI, BBRI, JSMR, LKPR, MPPA, UNTR, dan UNVR. Apabila investor sudah memiliki sahamsaham tersebut sebaiknya investor tidak menjual saham tersebut untuk memperoleh peluang kenaikan harga. Sedangkan bagi investor yang kebetulan sudah memiliki saham yang tergolong overvalued yaitu adro, bmri dan SCMA sebaiknya segera menjual saham tersejut.

\section{DAFTAR PUSTAKA}

Abdul, Halim. 2005. Analisis Investasi. Edisi Kedua. Jakarta: Salemba Empat.

Adler Haymans Manurung. 2004. Penilaian Perusahaan: Pendekaztan Sederhana Sampai Ekonometrika, Tangerang: PT Adler Manurung Press.

Alexander, Gordon J. and Sharpe, William F. 1995. Fundamental of Investment. Prentice Hall Inc. Englewood Cliffs. New Jersey.

Asnawi, Said Kelana, Chandra Wijaya. 2006. Metodologi Penelitian Keuangan: Prosedur, Ide dan Kontrol. Yogyakarta: Graha Ilmu.

Bodie, Z., Kane, A., Marcus, \& Alan, J. 2006. Investment. Terjemahan Zuliani dan Budi, Jakarta: Penerbit Salemba Empat

Damodaran, Aswath. 2002. Investment Valuation Tools and Techniques for Determining the Value of Any Asset. New Jersey: John Wiley $\&$ Sons, Inc

Darmadji, T. dan Fakhruddin. 2006. Pasar Modal di Indonesia. (Edisi 2). Jakarta: Salemba Empat.

Elton, Edwin J. and Gruber, Martin J. 1995. Modern Portfolio Theory and Investment Analysi. Fourth Edition. John Wiley \& Sons. Singapore.

Gill O. James dan Chatton Moira, Penerjemah: Dwi Prabaningtyas, Memahami Laporan Keuangan, PPM, Jakarta, 2003

Irene Silvia Permata, Kertahadi, Dan Topowijono, 2013. Penilaian Saham Dengan Menggunakan Metode Price Earning Ratio (PER) Dan Price Book Value (PBV)(Studi Pada Saham PT Bank Rakyat Indonesia (Persero), Tbk Yang Terdaftar Pada Bursa Efek Indonesia Periode 2003-2012). Juranl Administrasi Bisnis FIA Universitas Brawijaya.

Jogianto, Hartono, 2010. Teori Portofolio dan Analisis Investasi, Edisi Ketujuh Yogyakarta: BPFE.

Jones, Charles P., 2004, Investment, New York: Prentice-Hall 
Marmono, Singgih. (2012). Penilaian Kewajaran Harga Saham Sehingga Pertimbangan Investasi Di Bursa Efek Indonesia. Jurnal Bisnis Dan Management. Vol. 6, No. 1, Hlm: 69-78.

M. Sayyidin Noor dan Made Dudy Satyawan. 2014. Analisis Penilaian Harga Wajar Saham Studi Kasus Pada PT Multi Bintang Indonesia, Tbk, Jurnal Ilmu Manajemen Volume 2 Nomor 3

Nazwirman, 2008. Penilaian Harga Saham Dengan Price Earning Ratio (Per): Studi Kasus Pada Saham Industri Makanan Dan Minuman Di Bursa Efek Indonesia, Makara, Sosial Humaniora Vol. 12 No. 2: 98 - 106

Sri Dwi Ari Ambarwati (2008), Pengaruh Return Saham, Volume Perdagangan Saham, dan Varian Return Saham terhadap Bod Ask Spread Saham pada Perusahaan Manufaktur yang Tergabung dalam Indeks LQ45 Periode Tahun 2003-2005, Jurnal Sisat Bisnis Vol 12, No.1 Hal. 27-38.

Suad Husnan, 2003, Manajemen Keuangan Teori dan Penerapan (keputusan Jangka Pendek), Edisi keempat, BPFE, Yogyakarta.

Tambunan, Andy Porman. 2007. Menilai Harga Wajar Saham. Jakarta: Elex Media Komputindo.

Tandelilin, Eduardus. 2010. Portofolio dan Investasi Teori dan Aplikasi. Yogyakarta: Kanisius. 